\title{
Aloe macroclada from Madagascar Triggers Transient Bone Marrow Stem Cell Mobilization
}

Christian Drapeau $^{1 *}$, Kathy F. Benson ${ }^{2}$, John James ${ }^{3}$ and Gitte S. Jensen ${ }^{2}$

${ }^{1}$ Stemtech International, 2010 NW 150th Avenue, Pembroke Pines, FL 33028, USA

${ }^{2}$ Natural Immune System Labs, 1437 Esplanade Ave, Klamath Falls, OR 97601, USA

${ }^{3}$ Mioty Voajanahary, Madagascar, 1144 Lockland Ave, Winston Salem, NC 27103, USA

\begin{abstract}
Objective: Aloe has been used for the treatments of various ailments dating back almost 6000 years. There are more than 450 species of aloe coming from various parts of Africa and South America, and from the island of Madagascar that contains unique species endemic to the island. One such species is Aloe macroclada that has been used for centuries by the local residents as a remedy for a wide variety of ailments. We investigated whether the mechanism of action behind the wide-ranging health benefits of $A$. macroclada could be mobilization of bone marrow stem cells.

Methods: A. macroclada was prepared into small spherical pellets by Malagasy healers using traditional methods of fabrication. The traditional dose of three pellets was fed to 4 volunteers and the number of circulating stem cells was quantified 1, 2 and 3 hours after consumption using flow-cytometry.

Results: The usual dose and preparation of $A$. macroclada traditionally used in Madagascar triggered a significant increase (up to $53 \%$ ) in the number of circulating CD45dim CD34 and CD34+ ${ }^{+}$D $133^{+}$stem cells within 2 hours of consumption. This increase lasted more than 3 hours and was significant after 120 and 180 minutes of consumption.

Conclusion: Consumption of $A$. macroclada has been credited with significant improvements in a wide variety of heath conditions. This data suggest that stem cell mobilization may be an important mechanism of action behind the health benefits of $A$. macroclada.
\end{abstract}

Keywords: Aloe macroclada; Stem cell; Stem cell mobilization

\section{Introduction}

Aloe has been used for the treatments of various ailments dating back almost 6000 years. Aloe was found engraved in an Egyptian temple fresco dating back $4000 \mathrm{BC}$, and a Sumerian clay tablet dating around 2,200 $\mathrm{BC}$ mentioned the great healing power of aloe. The first detailed description of aloe's medicinal value can be found in the Ebers Papyrus written around 1550 BC in Egypt, describing the use of whole leaves, fresh gel, sap, and dried gel [1]. There are more than 450 species of aloe coming from various parts of Africa and South America, and from the island of Madagascar that contains unique species endemic to the island. One such species is Aloe macroclada that has been used for centuries by the local residents as a remedy for a wide number of ailments, including cardio-vascular diseases, hypertension, pulmonary infections, rheumatism, asthenia, and diabetes. It is traditionally considered by the Malagasy people as a factor of rejuvenation and longevity.

In Madagascar, the method of preparing A. macroclada has been passed down from generations to generations, and still today small round pellets of $A$. macroclada can be found in local markets. In brief, aloe plants are cut from the ground and hung on top of a bucket to collect the juice and gel. The plant is then charred and the ash is blended with the juice. The resulting blend is then rolled into small pellets whose moisture is adjusted by adding some gel, as needed, and then sun dried. Each dried bead-shape pellet weighs an average of $110 \mathrm{mg}$ and the common dosage is three pellets a day taken orally.

The active compounds and nutrients generally found in Aloe spp. include a wide range of minerals, essential amino acids, vitamins, tanins, aloetin, aloin, and polysaccharides such as polymannose and immune-modulating acemannan [2-4]. Other polysaccharidecontaining plants that have been historically associated with broad spectra of health benefits were shown to act at least in part by supporting the mobilization of bone marrow stem cells into the peripheral blood circulation $[5,6]$, thereby increasing the number of circulating stem cells available to participate to the process tissue repair [7]. In this study we investigated the effect of $A$. macroclada on stem cell mobilization, which would provide a mechanism of action for the various health benefits associated with $A$. macroclada.

\section{Methods}

\section{Reagents}

Phosphate-buffered saline (PBS) $(\mathrm{pH} 7.4)$, sodium azide, and bovine serum albumin were obtained from Sigma-Aldrich (St. Louis, MO, USA). The following monoclonal antibodies were purchased from Becton-Dickinson (San Jose, CA, USA): CD31-fluorescein isothiocyanate, CD34-peridinin-chlorophyll-protein complex (PerCP) and CD184 (CXCR4)-brilliant violet 421 (v421). The monoclonal antibody CD45-pacific orange (PO) and Cal-Lyse Lysing solution was purchased from Life Technologies (Carlsbad, CA). The monoclonal antibody CD133-PE was purchased from Miltenyi Biotec (San Diego, CA).

*Corresponding author: Christian Drapeau, Stemtech International, 2010 NW 150th Avenue, Pembroke Pines, FL 33028, USA, Tel: 954-715-6000 ext. 1003; E-mail: cdrapeau@stemtech.com

Received April 21, 2015; Accepted June 15, 2015; Published June 17, 2015

Citation: Drapeau C, Benson KF, James J, Jensen GS (2015) Aloe macroclada from Madagascar Triggers Transient Bone Marrow Stem Cell Mobilization. J Stem Cell Res Ther 5: 287. doi:10.4172/2157-7633.1000287

Copyright: (c) 2015 Drapeau C, et al This is an open-access article distributed under the terms of the Creative Commons Attribution License, which permits unrestricted use, distribution, and reproduction in any medium, provided the original author and source are credited. 


\section{Consumables}

Two different types of consumables were used in this study: $A$. macroclada traditionally prepared in Madagascar and a matching placebo. The traditional $A$. macroclada preparation was in the form of hand-rolled black pellets, prepared in Madagascar according to ancestral formulation, by mixing $A$. macroclada juice with ashes of the charred plant, along with some gel. The pellets were obtained by an ethnobotanist who verified source and speciation. To ensure a blinded placebo-controlled design, 3 pellets averaging a total of $335 \mathrm{mg}$ pellets were crushed and blended with green-colored rice flour, resulting in a dark-green powder that was encapsulated into rapidly dissolving veggie caps. Placebo capsules of similar appearance were prepared using the same dark-green colored rice flour. Study participants, nurses, and laboratory assistants were all blinded to the consumables.

\section{Study design}

A randomized, double-blinded, placebo-controlled crossover study design was used for this pilot study. Four people were recruited upon written informed consent approved by the Sky Lakes Medical Center Institutional Review Board (FWA 2603).

The study group included three females and one male with an average age of $49.3 \pm 21$ years, with no asthma and allergies requiring daily medication, known chronic illness, frequent recreational drug use, impaired digestive function (including previous major gastrointestinal surgery), or known allergies to aloe products.

The study participants were scheduled on two study days at least 1 week apart. Testing was always performed at the same time of the day for each person, the same day of the week, and always during the morning hours of 7-11 am to minimize the effect of circadian fluctuations. Because of the interference from exercise [8] and stress [9-12] with the release versus homing of lymphocytes, the study environment was tailored to avoid physical and mental stress prior to and during testing. On each study day, study participants completed a questionnaire to help monitor any exceptional stress-related circumstances that might be affecting the person on that day. Predetermined criteria for exclusion from data analysis included sleep deprivation and acute anxiety. After completing the questionnaire, volunteers were instructed to remain calm and inactive for 4 hours, comfortably seated in a chair. After the first hour, the baseline blood sample was drawn. Immediately after the baseline sample was drawn, an encapsulated test product was provided with water and consumed in the presence of a research assistant. Blood samples were drawn at 1,2 and 3 hours after ingestion of the test product. At each blood draw, $6 \mathrm{~mL}$ of blood was drawn into heparin for subsequent immunostaining.

\section{Immunostaining}

For each time point, $100 \mu \mathrm{L}$ of heparinized whole blood was stained in triplicate using the following 5-color staining panel: CD31-FITC, CD133-PE, CD34-PerCP, CD45-PO and CD184 (CXCR4)-v421. Staining was performed as recommended by Life Technologies for whole blood staining followed by the no-wash procedure for CalLyse fixation of white blood cells and lysing of red blood cells. In brief: samples were stained in the dark at room temperature for 15 min. followed by the addition of $100 \mu \mathrm{L}$ of Cal-Lyse Lysing solution and fixation for $10 \mathrm{~min}$. at room temperature. Red blood cells were then lysed by the addition of $1 \mathrm{~mL}$ of deionized water and further $10 \mathrm{~min}$. incubation in the dark at room temperature. Samples were stored at $4^{\circ} \mathrm{C}$ in the dark and acquired by flow cytometry within 24 hours using an acoustic-focusing Attune ${ }^{\text {Tx }}$ flow cytometer (Life
Technologies). Files of $>300,000$ events were collected on each triplicate sample.

\section{Statistical analysis}

Statistical significance was tested using Student's two-tailed, paired t-test with a $p$-value of $0<0.5$ indicating a significant difference between two data sets.

\section{Results}

No negative or undesirable effects were observed or reported by the participants.

This preliminary investigation revealed that $A$. macroclada pellets, produced by Madagascar natives according to ancestral formulation, triggered a rapid, transient increase in the number of two subsets of circulating stem cells.

\section{CD45dim CD34 ${ }^{+}$stem cells}

Consumption of an average of $335 \mathrm{mg}$ of A. macroclada preparation triggered an average increase of $3 \%, 32 \%$ and $29 \%$ at 60 , 120 and 180 minutes after consumption, respectively, in the number of CD45dim CD34 ${ }^{+}$cells in the peripheral blood circulation (Figure 1). Representative scatter dot plots are shown in Figure 2. When comparing the increases in CD45 dim CD34+ cells seen at 120 and 180 minutes post consumption of $A$. macroclada to the changes following consumption of placebo, these increases were significant $(\mathrm{p}<0.05)$.

When considering the actual number of circulating stem cells, the average number of CD45dim $\mathrm{CD} 34^{+}$cells in the peripheral blood circulation of the participants was $1.15,1.62,1.55(\mathrm{p}<0.04)$ and 1.60 $(\mathrm{p}<0.02)$ cells $/ \mu \mathrm{L}$ at time $0,60,120$ and 180 minutes after consumption, respectively, which translates to a maximum increase of $39 \%$ in the number of circulating stem cells. This provides for a maximum increase of 0.47 cells $/ \mu \mathrm{L}$, which equates to 2.35 million stem cells when considering an average $5 \mathrm{~L}$ of blood in the peripheral blood circulation.

\section{$\mathrm{CD}^{+} 4^{+} \mathrm{CD} 133^{+}$stem cells}

Consumption of an average of $335 \mathrm{mg}$ of A. macroclada preparation

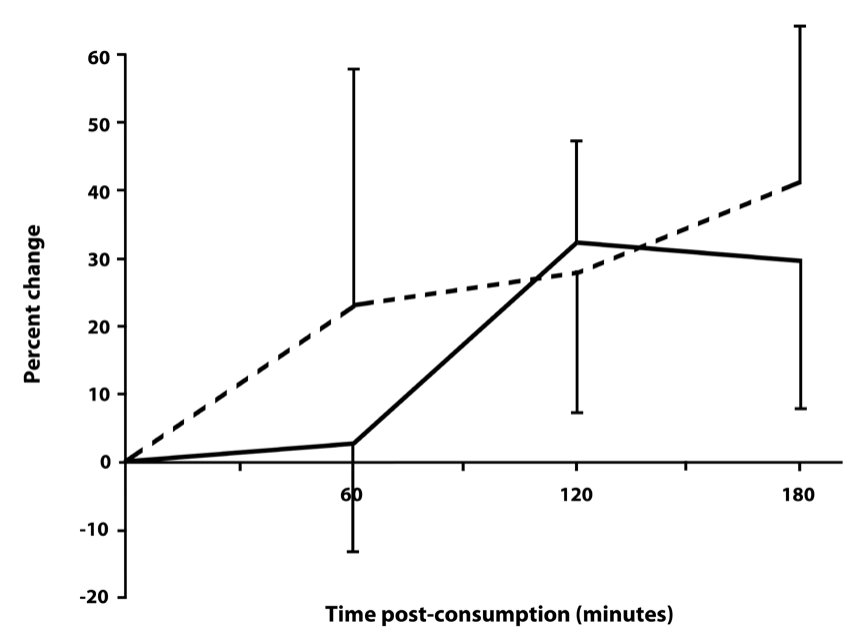

Figure 1: The percent change in circulating CD45dim CD34+ (solid line) and CD34+ CD133+ (dashed line) stem cells following consumption of $A$. macroclada is shown as averages \pm SEM. The percent change compared to baseline stem cell numbers in the blood circulation was calculated for each of the study participants, compensated for each person's changes after consuming placebo, and then averaged. 

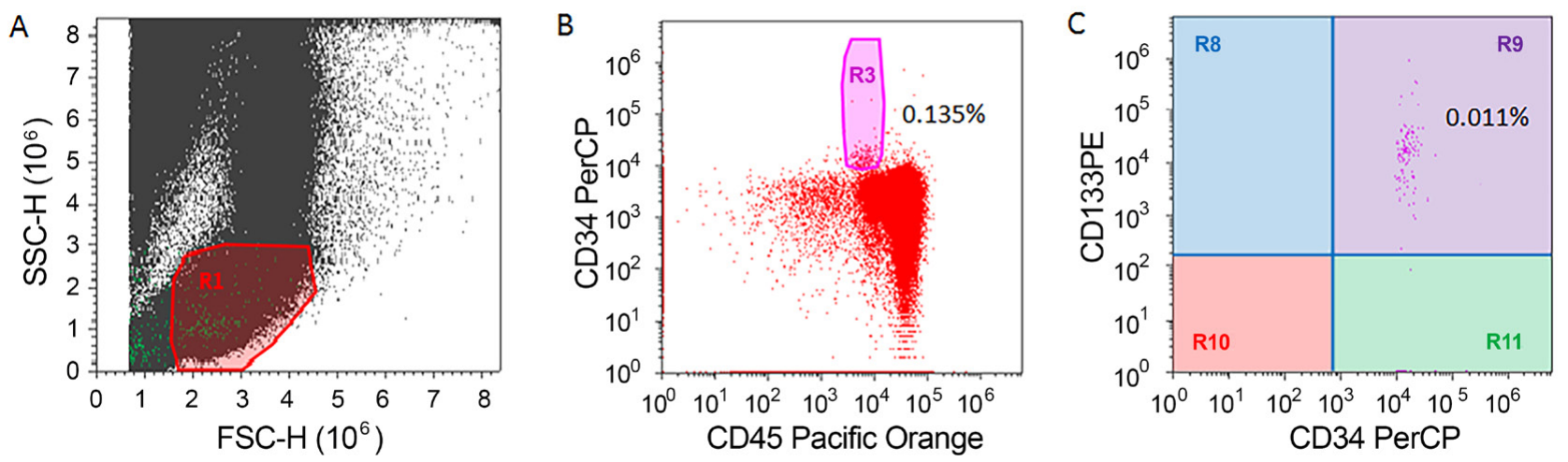

Figure 2: Flow cytometry analysis of peripheral blood. A. Representative profile of peripheral blood with respect to size (FSC) and granularity (SSC). The region defined by the electronic gate R1 excludes debris and contains cells with low granularity, including stem cells. B. Dot plot showing the staining pattern for CD45 and CD34 for particles within the R1 region. The region defined by the electronic gate R3 contains the CD45 dim CD34+ stem cells. C. Quandrant analysis of the R3 region showing fluorescence intensity for the stem cell markers CD34 and CD133, where quadrant R9 contains CD34+ CD133+ stem cells. The percentages shown are relative to the number of particles within region $\mathrm{R} 1$.

triggered an average increase of $23 \%, 27 \%$ and $41 \%$ at 60,120 and 180 minutes after consumption, respectively, in the number of CD34 $\mathrm{CD}_{133^{+}}$cells in the peripheral blood circulation (Figure 1). When comparing the increases in $\mathrm{CD} 34^{+} \mathrm{CD} 133^{+}$cells seen at 120 and 180 minutes post consumption of $A$. macroclada to the changes following consumption of placebo, these increases were significant $(\mathrm{p}<0.05)$.

When considering the actual number of circulating stem cells, the average number of $\mathrm{CD} 34^{+} \mathrm{CD} 133^{+}$cells in the peripheral blood circulation of the participants was $0.82,1.22,1.10$ and $1.26(\mathrm{p}<0.04)$ cells/ $\mu \mathrm{L}$ at time $0,60,120$ and 180 minutes after consumption, respectively, which translates to a maximum increase of $53 \%$ in the number of circulating stem cells. This provides for a maximum increase of 0.44 cells $/ \mu \mathrm{L}$, which equates to 2.20 million stem cells when considering an average $5 \mathrm{~L}$ of blood in the peripheral blood circulation.

\section{Discussion}

A. macroclada has been used for many generations in Madagascar, oftentimes referred to as vahona. Natives use it for a wide variety of benefits, going from general wellbeing to specific ailments such as diabetes, cardiovascular diseases and rheumatism. To our knowledge this is the first report of a possible mechanism of action behind the health benefits of $A$. macroclada.

Other plants and natural compounds have been documented to trigger bone marrow stem cell mobilization. For example, an extract from the cyanophyta Aphanizomenon flos-aquae was reported to trigger a $25-30 \%$ increase in the number of circulating stem cells within 60 minutes of consumption, which lasted 2-3 hours [5]. Fucoidan from the seaweed Undaria pinnatifida, also known as wakame, was also documented to transiently increase the number of circulating stem cells by up to $20 \%$ for more than 3 hours after consumption (unpublished), and to increase the baseline number of circulating stem cells after two weeks of daily consumption [6].

The effect of $A$. macroclada reported here was superior in magnitude to that reported by A. flos-aquae, and the effect lasted more than 3 hours after consumption. The long-term effect on the baseline level of stem cells was not investigated as part of this preliminary trial.

Aloe spp. has been reported in several studies to improve glucose tolerance and overall glucose metabolism. For example, oral intake of Aloe barbadensis significantly reduced blood glucose in alloxandiabetic mice within 5 days of treatment [13]. Consumption of Aloe vera juice and glibenclamide significantly reduce fasting blood glucose within two weeks in diabetic patients [14]. Similar results were reported with the use of Aloe vera gel alone [15]. However, none of these studies suggested a clear mechanism of action.

A linear relationship has been documented in humans between the number of circulating endothelial progenitor stem cells and the various phases of diabetes development, namely impaired fasting glucose, impaired glucose tolerance and insulin-dependent diabetes [16]. In other words, the development of diabetes is accompanied by a decline in the number of circulating stem cells. Circulating stem cells have been reported to have the capacity of migrating to the pancreas and differentiating into functional insulin-producing cells [17], and increasing the number of circulating stem cells has been reported to significantly improve the condition of streptozotocin-diabetic mice [18], as well as recently diagnosed insulin-dependent patients [19]. We therefore hypothesize that the effect of $A$. macroclada on stem cell mobilization could also be linked to other Aloe species, and that the benefits of Aloe spp. on diabetes and glucose metabolism might be mediated through stem cell mobilization. This is the focus of a current on-going investigation.

\section{Conflict of Interest}

Christian Drapeau is Chief Science Officer and co-owner of Stemtech International, Inc. John James is co-owner of Mioty Voajanahary, harvesting and processing Aloe macroclada in Madagascar. This study was funded by Stemtech International, Inc.

\section{References}

1. Park YI, Lee SK (2006) New perspectives on Aloe. New York: Springer.

2. Grace OM, Dzajic A, Jäger AK, Nyberg NT, Önder A, et al. (2013) Monosaccharide analysis of succulent leaf tissue in Aloe. Phytochemistry 93: 79-87. [PubMed]

3. Rodríguez ER, Martín JD, Romero CD (2010) Aloe vera as a Functional Ingredient in Foods. Crit Rev Food Sci Nutr 50: 305-326. [PubMed]

4. Im SA, Oh ST, Song S, Kim MR, Kim DS, et al. (2005) Identification of optimal molecular size of modified Aloe polysaccharides with maximum immunomodulatory activity. Int Immunopharmacol 5: 271-279. [PubMed]

5. Jensen GS, Hart AN, Zaske LA, Drapeau C, Gupta N, et al. (2007) Mobilization of human CD34+ CD133+ and CD34+ CD133(-) stem cells in 
Citation: Drapeau C, Benson KF, James J, Jensen GS (2015) Aloe macroclada from Madagascar Triggers Transient Bone Marrow Stem Cell Mobilization. J Stem Cell Res Ther 5: 287. doi:10.4172/2157-7633.1000287

Page 4 of 4

vivo by consumption of an extract from Aphanizomenon flos-aquae--related to modulation of CXCR4 expression by an L-selectin ligand? Cardiovasc Revasc Med 8: 189-202. [PubMed]

6. Irhimeh MR, Fitton JH, Lowenthal RM (2007) Fucoidan ingestion increases the expression of CXCR4 on human CD34+ cells. Exp Hematol 35: 989-994. [PubMed]

7. Drapeau C, Eufemio G, Mazzoni P, Roth GD, Stranberg S (2012) The therapeutic potential of stimulating endogenous stem cell mobilization. In Tissue Regeneration, GW Yip (Ed), Yong Loo Lin School of Medicine, National University of Singapore, Singapore.

8. Shephard RJ (2003) Adhesion molecules, catecholamines and leucocyte redistribution during and following exercise. Sports Med 33: 261-284. [PubMed]

9. Dimitrov S, Benedict C, Heutling D, Westermann J, Born J, et al. (2009) Cortisol and epinephrine control opposing circadian rhythms in T cell subsets. Blood 113: 5134-5143. [PubMed]

10. Atanackovic D, Schnee B, Schuch G, Faltz C, Schulze J, et al. (2006) Acute psychological stress alerts the adaptive immune response: stress-induced mobilization of effector T cells. J Neuroimmunol 176: 141-152. [PubMed]

11. Atanackovic D, Brunner-Weinzierl MC, Kröger H, Serke S, Deter HC (2002) Acute psychological stress simultaneously alters hormone levels, recruitment of lymphocyte subsets, and production of reactive oxygen species. Immunol Invest 31: 73-91. [PubMed]

12. Dimitrov S, Lange T, Nohroudi K, Born J (2007) Number and function of circulating human antigen presenting cells regulated by sleep. Sleep 30: 401411. [PubMed]

13. Ajabnoor MA (1990) Effect of aloes on blood glucose levels in normal and alloxan diabetic mice. J Ethnopharmacol 28: 215-220. [PubMed]

14. Bunyapraphatsara N, Yongchaiyudha S, Rungpitarangsi V, Chokechaijaroenporn O (1996) Antidiabetic activity of Aloe vera L. juice II. Clinical trial in diabetes mellitus patients in combination with glibenclamide. Phytomedicine 3: 245-248. [PubMed]

15. Yongchaiyudha S, Rungpitarangsi V, Bunyapraphatsara N, Chokechaijaroenporn O (1996) Antidiabetic activity of Aloe vera L. juice. I. Clinical trial in new cases of diabetes mellitus. Phytomedicine 3: 241-243. [PubMed]

16. Fadini GP, Boscaro E, de Kreutzenberg S, Agostini C, Seeger F, et al. (2010) Time course and mechanisms of circulating progenitor cell reduction in the natural history of type 2 diabetes. Diabetes Care 33: 1097-1102. [PubMed]

17. lanus A, Holz GG, Theise ND, Hussain MA (2003) In vivo derivation of glucosecompetent pancreatic endocrine cells from bone marrow without evidence of cell fusion. J Clin Invest 111: 843-850. [PubMed]

18. Hasegawa Y, Ogihara T, Yamada T, Ishigaki Y, Imai J, et al. (2007) Bone marrow (BM) transplantation promotes beta-cell regeneration after acute injury through BM cell mobilization. Endocrinology 148: 2006-2015. [PubMed]

19. Voltarelli JC, Couri CEB, Stracieri ABPL, Oliveira MC, Moraes DA, et al. (2007) Autologous nonmyeloablative hematopoietic stem cell transplantation in newly diagnosed Type 1 diabetes mellitus. JAMA 297: 1568-1576. [PubMed] 